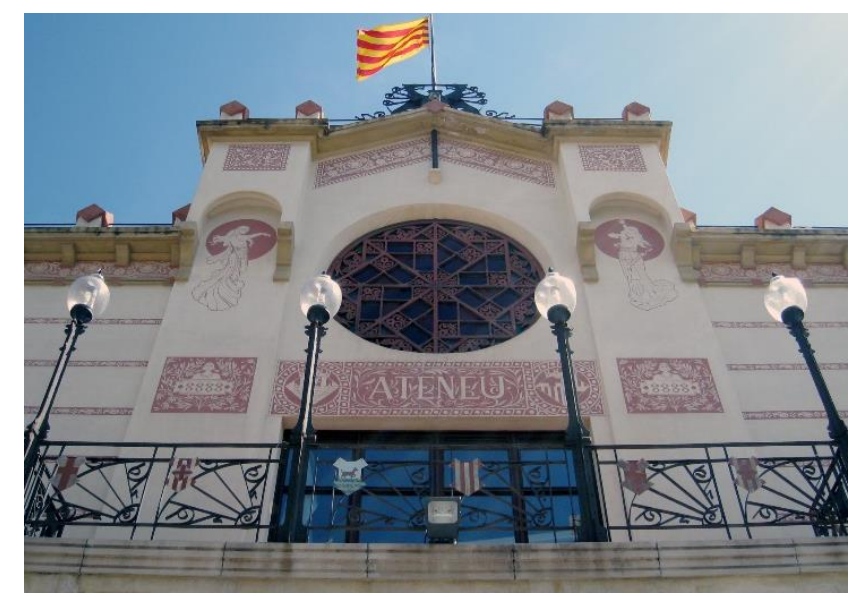

\title{
Em nome do Pai: \\ autoritarismo e discurso patriarcal n'O Ateneu, de Raul Pompéia
}

In the name of the Father:

Authoritarianism and patriarchal discourse in $O$ Ateneu, by Raul Pompeia

Franco Baptista Sandanello ${ }^{1}$

Resumo: O presente artigo discute elementos pontuais da narração do romance $O$ Ateneu (1888), de Raul Pompéia, e interpreta as rememorações de seu narrador - Sérgio - como desenvolvimento de um discurso de poder patriarcal, que, antes de criticar imparcialmente as mazelas do ensino em um internato da época, acaba por reproduzir, através da repetição do discurso paterno, o conservadorismo paralelamente trazido de casa. Neste sentido, pretende-se relativizar o elemento puramente memorialístico da narração em face do lugar ideológico desta mesma voz narrativa, que se torna, por si só, o ponto central da crítica de Pompéia ao Brasil Monárquico.

Palavras-chave: Raul Pompéia; Ateneu; Literatura brasileira; Narração.

Abstract: The present article discusses specific narrative elements of $O$ Ateneu (1888), a novel by Raul Pompeia, and interprets the recollections of its narrator - Sergio - as a development of patriarchal discourse, which, before criticizing the ills of education in a boarding school of its period, turns out to reproduce, through the repetition of his father's speech, a parallel conservatism, brought from home. In this regard, this article aims to relativize the purely memorialistic elements of $O$ Ateneu's narration in face of the ideological basis of its narrative voice, here considered, in itself, the center point of Pompéia's critique of Brazilian Monarchy.

Keywords: Raul Pompéia; Ateneu; Brazilian literature; Narration.

\footnotetext{
1 Pós-Doutorando - Programa de Pós-Graduação em Estudos Literários da UNESP - Universidade Estadual Paulista - Campus Araraquara. Endereço: Rod. Araraquara-Jaú Km 1, 14800-901, Araraquara, SP, Brasil. Email: fbsandanello@gmail.com
} 


\section{Introdução}

Por mais acidentado que tenha sido o percurso da recepção crítica d'O Ateneu, não parece ter ocorrido que se tratasse, em suma, de um romance de tese. Não, ao menos, no sentido de uma tese preconcebida, em que o material narrativo servisse de comprovação e confirmação de um argumento. No entanto, é o que acontece (com certa liberdade conceitual) desde o início da narração do romance, onde se enuncia com a maior naturalidade, através da fala premonitória do pai, a "tese" de que o mundo é uma luta, e de que é preciso coragem para enfrentá-lo. Neste sentido, e inesperadamente, a fala paterna parece inaugurar, antecipar e encerrar em si o sentido humano do texto, o que requer de qualquer análise narrativa d'O Ateneu uma discussão sobre o sentido de sua aproximação com o discurso paterno (e, por extensão, com o plano doméstico), o qual, apesar de constituir um mero aviso, é logo tido pelo narrador como a mais pura "verdade".

Convém começarmos do começo. E o começo do romance, curiosa e espantosamente, não foi de início tal como o conhecemos. A primeira página da obra, entregue a Capistrano de Abreu pouco antes de sua publicação em jornal, extraviou-se, e somente muito depois foi recuperada, quando já publicadas as duas primeiras edições d'O Ateneu. ${ }^{2}$ A versão original do texto na íntegra, recuperada em livro por Eugênio Gomes (1953, p. 113-116), consta de dois parágrafos, em diversos sentidos esclarecedores quanto ao que viria a ser, depois, o capítulo inicial da obra:

Quando ele morreu fizeram parar o relógio na hora cruel - seis da manhã. O sol acabava de erguer-se, abrindo sobre a terra a larga mão de ouro, benção matinal da luz, sobre a ressurreição da vida - quando ele partiu para a eterna sombra. O mostrador imóvel parecia igualmente alcançado pela morte e a fixidez do ponteiro ampliava-nos a dor na alma, com a permanência implacável da recordação, sangrando, rebelde ao tempo que cicatriza; como se para nós que o queríamos devesse ficar a existência nada mais que o prolongamento intérmino daquela hora, eco imortal das seis pancadas trêmulas do velho relógio, culto sagrado e doloroso de uma memória.

Por esses dias excepcionais surgiram-me no espírito vivazes como nunca as imagens do passado, as lembranças principalmente da primeira mocidade em que mais senti a sofreguidão amorosa dos seus esforços, pobre amigo que chorava as minhas lágrimas e rejubilava das minhas alegrias, protegendo-me confiado e nobre, protegendo-me sempre com o entusiasmo nervoso do seu afeto, admirando-me na benevolência do seu grande coração esperançado, consolidando-me $o$

\footnotetext{
${ }^{2}$ A carta encontra-se reproduzida, textual e graficamente, na biografia de Pompéia escrita por Camil Capaz (2001).
} 
caráter de menino pelo apoio enérgico da experiência dos seus provados anos.

Conquanto o autor tenha alterado a seguir as primeiras linhas do romance, estabelecendo na versão final do texto, tanto na impressão em folhetim, quanto nas provas entregue à livraria Francisco Alves, uma versão diversa da que aqui se reproduz, há como que um esclarecimento mútuo entre esses dois parágrafos "inaugurais" e os parágrafos finais d'O Ateneu, pontos extremos e paralelos do universo ficcional aí compreendido.

Aqui, percebemos uma dependência total das recordações do narrador para com a memória do pai, falecido há pouco. As lembranças da "primeira mocidade" acodem como ilustrações da "benevolência do seu grande coração esperançado", numa série de flashes da relação amorosa pai-filho. E no instante da perda do ente querido é que se propõe o narrador a fixar o instantâneo de suas emoções, ou, em outras palavras, a "Crônica de saudades" que se lhe acomete.

Par a par, e por intermédio da saudade, soma-se a premência do tempo, que universaliza a tragédia da família e amplia o sentido particular da dor na imagem exemplar do relógio parado às seis horas da manhã, por contraste ao nascer do sol. Como era de costume na época a interrupção do relógio no instante do falecimento (memento mori invertido, onde a morte do indivíduo faz parar o tempo coletivo), há como que uma linha entre uma geração que se vai e outra que chega, tomando seu lugar. No momento da investidura do mando está o narrador: a formação de si, o "currículo" que lhe autoriza a passagem - a entrada no colégio - em suma, o assunto do livro.

Assim, por mais que "devesse ficar a existência nada mais que o prolongamento intérmino daquela hora, eco imortal das seis pancadas trêmulas do relógio", a própria capacidade de enunciar-se a si e a outrem, de contar sua história, autoriza o autor dessas memórias a seguir adiante em sua retomada sentimental do passado; a experiência do pai antecede e complementa a sua, e o narrador somente o é como filho, enquanto descendente daqueles "provados anos" cujo contato busca traduzir em palavras.

Contudo, tais observações não condizem nem com o sentido de tempo nem com o de saudade presentes na versão "final" d'O Ateneu. Observemos, no outro extremo do romance, o último parágrafo, em que discorre sucinta e definitivamente sobre o sentido de ambos os termos: "Saudades verdadeiramente? Puras recordações, saudades talvez, 
se ponderarmos que o tempo é a ocasião passageira dos fatos, mas sobretudo - o funeral para sempre das horas. (POMPÉIA, 1981, p. 272) ${ }^{3}$

Do lado oposto, acabamos por encontrar, de fato, o oposto: não se trata mais do culto da memória do pai, mas da destruição do passado, “dos fatos”. Aqui, não há mais saudade, mas apenas acerto de contas, absolutamente contrário ao sentido emotivo anterior. Pois, finalmente, para o narrador, a saudade encontra-se deformada e reduzida a "puras recordações, saudades talvez", se consideradas do ponto de vista de sua incapacidade de atingir o presente - e, está claro, de perpetuar qualquer memória (não obstante constitua o discurso do narrador um discurso memorialístico).

Logo, de uma dependência completa para com o discurso paterno, presente na versão inicial do romance, transita-se para uma aparente independência de tudo, num elogio ao poder destrutivo da memória. Em se tratando de um romance que discorre sobre os primeiros anos da vida escolar, é natural que a tensão entre universo doméstico x público, liberdade x dependência etc., polarizadas nos três parágrafos citados, figurem dentre alguns dos tópicos mais centrais. Também são naturais os questionamentos decorrentes da aproximação dessas duas passagens: por qual (is) razão (ões) o escritor vai de oito a oitenta, alterando poucos meses antes da publicação o sentido original de sua obra?

Há diversas razões para esse desnível entre os dois extremos do texto, mas concordamos com Camil Capaz (2001) de que o mais plausível seja o da tentativa de distanciamento do escritor para com sua obra. Seu pai, Antonio d'Ávila Pompéia, morrera a 23 de março de 1884, às seis e meia da manhã, fazendo com que o jovem Raul, ainda aluno de Direito em São Paulo, permanecesse dois meses desolado na Corte, mesmo após os contratempos com a Faculdade. Ademais, como afirma ainda o biógrafo:

Veja-se de saída o problema da idade de Sérgio, o narrador da história na primeira pessoa: na introdução primitiva do romance - existente na Biblioteca Nacional e abandonada na versão definitiva - o autor dizia ter nove anos ao entrar no internato, que é, aliás, a verdadeira idade do seu ingresso no Colégio Abílio, cenário principal da história; passou a dez anos, na versão publicada no jornal; e finalmente a onze na versão definitiva em livro. Tal hesitação, além de tentar desligar o romance de suas ligações biográficas, destinava-se a tornar mais críveis certas sutilezas de pensamento e as manifestações da sexualidade de Sérgio [...]. (CAPAZ, 2001, p. 106)

\footnotetext{
${ }^{3}$ A partir desta nota, citaremos o romance apenas como OA, dada a profusão de referências subsequentes a partir desta edição.
} 


\title{
Duas festas, dois espectadores, uma só atitude
}

Os parágrafos iniciais do romance, no tocante à dependência do narrador ante a “tese" paterna, não são tão categóricos quanto aqueles originais, mas indicam, ainda que de maneira modulada, a influência decisiva do pai sobre o menino / adulto:

\begin{abstract}
"Vais encontrar o mundo, disse-me meu pai, à porta do Ateneu. Coragem para a luta."

Bastante experimentei depois a verdade deste aviso, que me despia, dum gesto, das ilusões de criança educada exoticamente na estufa de carinho que é o regime do amor doméstico; diferente do que se encontra fora, tão diferente, que parece o poema dos cuidados maternos um artifício sentimental, com a vantagem única de fazer mais sensível a criatura à impressão rude do primeiro ensinamento, têmpera brusca da vitalidade na influência de um novo clima rigoroso. Lembramo-nos, entretanto, com saudade hipócrita, dos felizes tempos, como se a mesma incerteza de hoje, sob outro aspecto, não nos houvesse perseguido outrora, e não viesse de longe a enfiada das decepções que nos ultrajam.

Eufemismo, os felizes tempos, eufemismo apenas, igual aos outros que correram como melhores. Bem considerando, a atualidade é a mesma em todas as datas. Feita a compensação dos desejos que variam, das aspirações que se transformam, alentadas perpetuamente do mesmo ardor, sobre a mesma base fantástica de esperanças, a atualidade é uma. Sob a coloração cambiante das horas, um pouco de ouro mais pela manhã, um pouco mais de púrpura ao crepúsculo - a paisagem é a mesma de cada lado, beirando a estrada da vida. (OA, p. 29, 31)
\end{abstract}

Separemos, primeiramente, os lugares temporais envolvidos nas primeiras linhas do romance: o conselho paterno, que abre a narrativa em tom profético, visa o futuro, e antecipa uma relação conflituosa que perpassará toda a obra; por sua vez, o narrador encontra-se no momento presente da narração, de onde avalia as palavras paternas como "verdade"; e, finalmente, a apreensão dessas primeiras experiências pertence ao passado da voz narrativa, que arremata afirmando - "bastante experimentei depois a verdade deste aviso [...]." Essa distinção temporal inicial, que parece elementar e até dispensável, adquire uma importância maior quando percebemos que, logo a seguir, toda oposição é desfeita pelo narrador: passado, presente e futuro confluem numa única mensagem de ressentimento, para além dos limites do lar e do internato, pois "parece o poema dos cuidados maternos um artifício sentimental, com a vantagem única de fazer mais sensível a criatura à impressão rude do primeiro ensinamento". Isto equivale a dizer que, para além da problemática temporal do romance, colocam-se como imperativos os problemas existenciais do narrador, que transfere o conflito com o colégio para a vida inteira, e interpreta aquilo mesmo que diz (por intermédio do pai) como falso e verdadeiro simultaneamente: nesses termos, se a transferência de um meio 
para outro gera desconforto, não deve haver justiça em parte alguma, pois, de um lado, nada é exigido de si, e, de outro, tudo o é; assim, inadaptação torna-se desde logo sinônimo de injustiça tão somente pela possibilidade de essa última existir, e o que seria uma etapa difícil da vida representa uma negação dela toda, uma prescrição, como se ao entrar no colégio desaparecesse o lar, e, ao retornar a esse, desaparecesse também o colégio. Embora a argumentação seja falha (inadaptação particular como sinônimo de injustiça pública), ela é sempre "atual", e confirma a premência dos primeiros ensinamentos sobre os demais, pois, “[...] feita a compensação dos desejos que variam, das aspirações que se transformam, alentadas perpetuamente do mesmo ardor, sobre a mesma base fantástica de esperanças, a atualidade é uma”, o que muito se adequa à confirmação pura e simples do aviso paterno. ${ }^{4}$

Urge, todavia, o momento de separação desse espaço doméstico, alimento básico das convicções do narrador:

\begin{abstract}
Destacada do conchego placentário da dieta caseira, vinha próximo o momento de se definir a minha individualidade. Amarguei por antecipação o adeus às primeiras alegrias; olhei triste os meus brinquedos, antigos já! os meus queridos pelotões de chumbo! espécie de museu militar de todas as fardas, de todas as bandeiras, escolhida amostra da força dos estados, em proporções de microscópio, que eu fazia formar a combate como uma ameaça tenebrosa ao equilíbrio do mundo; que eu fazia guerrear em desordenado aperto [...] com uma facilidade de Providência Divina, intervindo sabiamente, resolvendo as pendências pela concórdia promíscua das caixas de pau. [...] Mas um movimento animou-me, primeiro estímulo sério da vaidade: distanciava-me da comunhão da família, como um homem! (OA, p. 31-32)
\end{abstract}

Apesar de estar suposta e "perfeitamente virgem para as sensações da nova fase", destacando que "vinha próximo o momento de se definir a [sua] individualidade", percebemos que o caráter de Sérgio já está delineado em sua postura altiva para com os brinquedos, que, "com uma facilidade de Providência Divina, intervindo sabiamente", consegue apaziguar as discórdias dos soldados de chumbo "pela concórdia promíscua das caixas de pau". Qual o motivo, então, dessa inversão, dando por incompleto o que está pronto, às perfeições de uma Providência? Antes de qualquer contato com o colégio

\footnotetext{
${ }^{4}$ Uma interpretação distinta desses parágrafos iniciais é a de Júlio Valle (2010), que, ao invés de ressaltar a importância do discurso paterno, aponta a concorrência de três elementos: a "ilusão" (encontro com a vida extrafamiliar); a "desilusão" (encontro com o microcosmo da vida em sociedade); e a "explanação" (encontro de Sérgio adulto com Sérgio menino, enquanto testemunho artístico e científico). Julgamos, todavia, que a importância do discurso paterno sobre a revisitação do passado incida sobre todos os três elementos, pois ela, a um só tempo, prepara a ilusão do menino, desilude-o quanto à vida em sociedade e serve de mote às recordações do narrador.
} 
de Aristarco - que se mostrará, dentro em pouco, como instituição repressiva, de ensino compartimentado e estanque à realidade dos meninos -, sua personalidade sai de casa inteiriça, dominadora, a rotular dentro de uma gaveta (pretenso "equilíbrio do mundo") elementos conflitantes entre si.

Acompanhado pelo pai, todavia, o Ateneu não lhe parece tão ruim:

A primeira vez que vi o estabelecimento, foi por uma festa de encerramento de trabalhos. Transformara-se em anfiteatro uma das grandes salas da frente do edifício, exatamente a que servia de capela; paredes estucadas de suntuosos relevos, e o teto aprofundado em largo medalhão, de magistral pintura, onde uma aberta de céu azul despenhava aos cachos deliciosos anjinhos, ostentando atrevimentos róseos de carne [...] Desta ante-sala, trepado a uma cadeira, eu espiava. Meu pai ministrava-me informações. Diante da arquibancada, ostentava-se uma mesa de grosso pano verde e borlas de ouro. Lá estava o diretor, o ministro do império, a comissão dos prêmios. Eu via e ouvia. Houve uma alocução comovente de Aristarco; houve discursos de alunos e mestres; houve cantos, poesias declamadas em diversas línguas. [...] A bela farda negra dos alunos, de botões dourados, infundia-me a consideração tímida de um militarismo brilhante, aparelhado para as campanhas da ciência e do bem. A letra dos cantos, em coro dos falsetes indisciplinados da puberdade; os discursos, visados pelo diretor, pançudos de sisudez, na boca irreverente da primeira idade, como um Cendrillon malfeito da burguesia conservadora, recitados em monotonia de realejo e gestos rodantes de manivela, ou exagerados, de voz cava e caretas de tragédia fora de tempo, eu recebia tudo convictamente, como o texto da bíblia do dever; e as banalidades profundamente lançadas como as sábias máximas do ensino redentor. (OA, p. 35-36)

A partir deste primeiro contato efetivo com o colégio, Sérgio descreve o anfiteatro improvisado na capela do Ateneu, onde destaca a concorrência de elementos profanos e seculares na constituição da aura (excessiva) da ocasião: no relevo das paredes, os anjos ostentam "atrevimentos róseos de carne", e agitam os pés e as mãos lascivamente; diante da arquibancada, é disposta "uma mesa de grosso pano verde e borlas de ouro" onde se sentam o diretor e o ministro do Império, como para um culto; na farda dos alunos, confundem-se o militarismo e "as campanhas da ciência e do bem"; nos cantos entoados, escondem-se os primeiros impulsos sexuais detrás dos "falsetes indisciplinados da puberdade"; nos discursos, "pançudos de sisudez", há o suporte imperfeito e ridículo da "boca irreverente da primeira idade", que interpreta um conto de fadas de Perrault ou "em monotonia de realejo e gestos rodantes de manivela, ou exagerados, em voz cava e caretas de tragédia fora de tempo", como para indicar a generalizada falta de trabalho intelectual. Contrariamente a tal espetáculo profano e hipócrita, Sérgio, acompanhado pelo pai numa ante-sala contígua - portanto, dentro e 
fora da festa -, "recebia tudo convictamente, como o texto da bíblia do dever" (como bom "devoto"), e "as banalidades profundamente lançadas como as sábias máximas do ensino redentor" (como bom "aluno"). O que é curioso destacar é que, de modo geral, as formalidades do ensino institucionalizado, nessa polarização culto $\mathrm{X}$ ciência que desmente a cientificidade e imparcialidade letivas, não bastam ainda para criar um universo público, por oposição ao privado - doméstico; o que motiva Sérgio a observar de fora o espetáculo dos professores e alunos é tão somente curiosidade, não coragem: o grosso das informações é-lhe ministrado ainda pelo pai.

De qualquer forma, pelo sim ou pelo não subentendido nessas variáveis (pouco contato efetivo com a cena, mediação do pai etc.), percebe-se uma ênfase um tanto excessiva do narrador na ingenuidade do protagonista, apto desde sempre para o ensino, seja ele moral, religioso, doméstico, formal... o que irá se confirmar logo a seguir, quando, ainda de braços com o pai, demonstra uma preocupação mais incisiva com a opinião alheia ao verem postos no mesmo plano os termos de "mestre" e de "pai", a par com a potestade divina, no discurso do professor Venâncio:

Um discurso principalmente impressionou-me. À direita da comissão dos prêmios, ficava a tribuna dos oradores. Galgou-a firme, tesinho, o Venâncio, professor do colégio, a quarenta mil-réis por matéria, mas importante, sabendo falar grosso, o timbre de independência, mestiço de bronze, pequenino e tenaz, que havia de varar carreira mais tarde. [...] "O mestre, perorou Venâncio, é o prolongamento do amor paterno [...]. Devemos ao pai a existência do corpo; o mestre cria-nos o espírito (sorite de sensação), e o espírito é a força que impele, o impulso que triunfa, o triunfo que nobilita [...] Acima de Aristarco Deus! Deus tão-somente; abaixo de Deus - Aristarco."

[...] Eu me sentia compenetrado daquilo tudo; não tanto por entender bem, como pela facilidade da fé cega a que estava disposto. (OA, p. 36-38)

O primeiro elemento importante do trecho é a falsa independência de Venâncio, traduzida em duas chaves - a econômica e a racial. Apesar de o menino Sérgio emprestar um ouvido ao mestre, o narrador adulto não ignora o fato de que ele está ali por dinheiro, e que, por isso mesmo, tudo o que venha a dizer de estofo moral acabe por ser relativo ou provisório, conforme as necessidades do momento e do investidor. Sua função, assim, é a de conferir um brilho excessivo (e imerecido) ao assunto em pauta, independente de crenças pessoais, como o de atribuir ao trabalho impessoal do mestre “o prolongamento do amor paterno", como reconhecemos desde já (se não o fizemos ainda) insubstituível para o narrador. Além de mercenário, Venâncio carrega um 
segundo estigma aos olhos de Sérgio, um pouco menos evidente, mas tão importante quanto o primeiro: Venâncio é mulato, "mestiço de bronze", o que, numa sociedade escravocrata e fortemente rural como a do Brasil oitocentista, não lhe credencia uma posição de destaque, como a de professor e orador, perante os internos, "fina flor da mocidade brasileira", nem perante seus pais, representantes da seleta oligarquia brasileira, em que "não havia família de dinheiro, enriquecida pela setentrional borracha ou pela charqueada do sul, que não reputasse um compromisso de honra com a posteridade doméstica mandar dentre seus jovens, um, dois, três representantes abeberar-se à fonte espiritual do Ateneu." (OA, p. 35)

Desconsiderando o salário de fome de Venâncio de quarenta mil-réis por matéria (que faz duvidar da lisura de Aristarco como empregador), os termos do discurso do professor destacam ainda a verbosidade retórica e servil do ensino da época, em que Venâncio fatalmente "havia de varar carreira mais tarde". De resto, é bastante temerária, se não improvável, a aproximação que faz entre Deus e o diretor do colégio, justamente em um discurso proferido na ocasião de fechamento do ano letivo e - por extensão - de apelo às famílias conservadoras de então. O tom do contraste é exagerado, e logo entendemos que não quer ser verossímil. Antes disso, colocando até certo ponto sua opinião na fala relatada de Venâncio, em citação direta o que deveria estar em discurso indireto, no corpo do texto (PACHECO, 1971), ${ }^{5}$ o relato do narrador nos fornece possivelmente uma caricatura do que teria dito o professor, ressaltando, em contrapartida, e mais uma vez, a ingenuidade do menino, cuja "docilidade" a essas palavras fantásticas se explica claramente pela "fé cega" a que estava disposto, pois, como confessa em falsete, o menino parecia "não entender bem". Quem sabe a presença do pai, todo o tempo a seu lado, tenha dispensado esses hiatos do discurso?

Ainda protegido pela vigilância paterna, o segundo contato com o colégio evidencia uma preocupação maior de Sérgio para com a opinião alheia, numa observação mais atenta, mas não menos entusiasmada, do espaço físico do Ateneu:

As galas do momento faziam sorrir a paisagem. O arvoredo do imenso jardim, entretecido a cores por mil bandeiras, brilhava ao sol vivo com o esplendor de estranha alegria; os vistosos panos, em meio da ramagem, fingiam flores colossais, numa caricatura extravagante de

\footnotetext{
${ }^{5}$ Mais especificamente, afirma João Pacheco (1971, p. 148): “A narração não obedece a uma ordem cronológica; tem, porém, uma forma analítica, impera na frase um torneio raciocinante. Ora o autor toma de um personagem, sonda-o, perscruta-o, explica-o. Ora isola um fato, abstraindo-o do espaço e do tempo. Vai e volta sobre os acontecimentos. Encaixa no contexto narrativo, em discurso direto, o que deveria estar em diálogo ou, se naquele, em modo indireto".
} 
primavera [...]. Meu pai prendia-me solidamente o pulso, que me não extraviasse. A princesa imperial, Regente nessa época, achava-se à direita em gracioso palanque de sarrafos. Momentos depois, adiantavam-se por mim os alunos do Ateneu. Cerca de trezentos; produziam-me a impressão do inumerável. [...] Não posso dar ideia do deslumbramento que me ficou desta parte. Uma desordem de contorções, deslocadas e atrevidas; uma vertigem de volteios à barra fixa, temeridades acrobáticas ao trapézio, às perchas, às cordas, às escadas [...]. O coração pulava-me no peito com um alvoroço novo, que me arrastava para o meio dos alunos, numa leva ardente de fraternidade. $\mathrm{Eu}$ batia palmas; gritos escapavam-me, de que me arrependia quando alguém me olhava. (OA, p. 39-41) ${ }^{6}$

Assim como na primeira festa presenciada por Sérgio e seu pai, há algo de deslocado na apresentação geral da solenidade, embora o protagonista pareça ver ainda com bons olhos o todo da solenidade. A decoração campestre do colégio, na qual "os vistosos panos, em meio da ramagem, fingiam flores colossais"; o militarismo dos exercícios de ginástica, resumido a uma "desordem de contorções, deslocadas e atrevidas"; a reação do menino, a vibrar vergonhosamente, como confessa o narrador, entre palmas e gritos: tudo parece indicar não o ânimo inspirado pela ocasião, mas antes sua (futura) animosidade, onde a coragem recomendada pelo pai se mistura à aversão pelo novo - e logo, incontrolável - espaço coletivo. É curioso notar que, talvez pelo suporte do pai, Sérgio veja com olhos combativos e excitados os dois espetáculos, antes que pela sugestão dos momentos isolados, pois em meio à entrega dos prêmios, o olhar do protagonista se detém sobre a família do diretor, e logo destaca, altivamente, o fracasso de seu poder sobre o filho, Jorge:

Aristarco arrebentava de júbilo. Pusera de parte o comedimento soberano que eu lhe admirara na primeira festa. De ponto em branco, como a rapaziada, e chapéu-do-chile, distribuía-se numa ubiquidade impossível de meio ambiente. [...] Ator profundo, realizava ao pé da letra, a valer, o papel diáfano, sutil, metafísico, de alma da festa e alma do seu instituto. Uma coisa o entristeceu, um pequenino escândalo. Seu filho Jorge, na distribuição dos prêmios, recusara-se a beijar a mão da princesa, como faziam todos ao receber a medalha. Era republicano o pirralho! Tinha já aos quinze anos as convicções ossificadas na espinha inflexível do caráter! Ninguém mostrou perceber a bravura. Aristarco, porém, chamou o menino à parte. Encarou-o silenciosamente e - nada mais. E ninguém mais viu o republicano! Consumira-se naturalmente o infeliz, cremado ao fogo

\footnotetext{
${ }^{6}$ A partir da observação do narrador a respeito da Princesa Isabel, "regente nessa época", podemos situar a situação descrita por volta do ano de 1871. Conforme indicação de Camil Capaz (2001, p. 108): "A princesa Isabel esteve à frente do Império entre maio de 1871 e março de 1872, por ocasião da primeira viagem de d. Pedro à Europa". Em se tratando de uma festa de conclusão dos trabalhos do ano letivo, a presença da Princesa Regente assinala o final do ano de 1871 como primeiro marco cronológico d' $O$ Ateneu.
} 
daquele olhar! Nesse momento as bandas tocavam o hino da monarquia jurada, última verba do programa. (OA, p. 42-43)

Se Aristarco é "a um tempo a alma da festa e alma do seu instituto", e, como vimos mais atrás, a função do mestre está mesclada ao amor paterno - e esse é o argumento que se esconde por detrás da apresentação das duas primeiras festividades do internato - que dizer de um pedagogo renomado, mestre e diretor de sua instituição, já na etimologia de seu nome prenunciado como "ótimo chefe" (BRAYNER, 1979, p. 144), que não consegue educar o próprio filho? Pois, nos trechos apontados, a falta de compostura, frente ao decoro excessivo das festas, equivale à falta de educação (que como se costuma dizer, vem do berço). Em todo caso, não se trata de uma desavença familiar qualquer, mas de um desacordo fundamental entre o plano doméstico e o plano público, ante a opinião política. Apresentado à Princesa Regente, Jorge recusa-se a beijar sua mão, renegando, simultaneamente, o beija-mão a Aristarco - que, como alma do instituto, deveria ser monarquista, e, de fato, investira "a última verba do programa" na execução "do hino da monarquia jurada".

Conquanto as convicções políticas de Jorge se desfaçam com apenas um olhar de repreensão de seu pai - "e ninguém mais viu o republicano!" -, não se elide na passagem o desapreço do narrador por quaisquer dos ideários políticos em jogo. ${ }^{7} \mathrm{O}$ apoio do pai dispensa o apoio de outrem - de um partido, de uma causa -, e a orfandade provisória de Jorge basta para ridicularizá-lo, ele, que supostamente "já aos quinze anos [tinha] as convicções ossificadas na espinha inflexível do caráter!”. Some-se a isto a observação de Sérgio sobre a cor de Venâncio, e teremos esboçado por ora o perfil do narrador à imagem e semelhança do pai, representante de uma elite enriquecida pela Monarquia e pelo trabalho escravo, o que enfeixa, de certa forma, a reflexão da dimensão social da obra, pois, como "autêntico representante da burguesia [deslocada de seu contexto europeu, ele] implica uma visão 'por dentro' e, ao mesmo tempo, uma denúncia visível, em todos os momentos, na ótica da personagem Sérgio." (ABDALA JR., 1999, p. 153) ${ }^{8}$

\footnotetext{
${ }^{7}$ Diversos intérpretes do romance, como Flávio Loureiro Chaves (1979), optaram por ver no narrador uma recusa da Monarquia, ou até mesmo uma manifestação do jacobinismo crescente de Pompéia. A passagem, contudo, enseja um desprezo de ordem bastante classista pelo ideário republicano, o que não impede, a contrapelo, uma leitura da posição social privilegiada de Sérgio pelo privilégio de sua posição central como narrador-memorialista.

${ }^{8}$ Alfredo Bosi (2002, p. 131), ao considerar esta especificidade d'O Ateneu, observa de maneira inversa, na correspondência entre a narração de Sérgio e a hipocrisia do colégio, uma postura ideologicamente resistente de Pompéia, que opta por criticar o vazio dos discursos da época a partir de seu vazio interior: "Essa gama de possibilidades poderá também ser testada nas relações que aproximam narrativa e
} 


\section{A separação}

As duas entrevistas particulares com Aristarco demarcam os últimos momentos de Sérgio em companhia do pai nas dependências do Ateneu. Como dantes, o menino encara tudo com certa animosidade e altivez, mas já começa a ponderar a validade da instituição enquanto tal, ao ver, pela primeira vez, o diretor em trajes menos formais, em sua residência (imediatamente ao lado do colégio):

O diretor recebeu-nos em sua residência, com manifestações ultra de afeto. Fez-se cativante, paternal; abriu-nos amostras dos melhores padrões do seu espírito, evidenciou as faturas do seu coração. $\mathrm{O}$ gênero era bom, sem dúvida nenhuma; [...] apesar do paletot de seda e do calçado raso com que se nos apresentava [...] Verdade é que não era fácil reconhecer ali, tangível e em carne, uma entidade outrora da mitologia das minhas primeiras concepções antropomórficas; logo após Nosso Senhor, o qual eu imaginara velho, feiíssimo, barbudo, impertinente, corcunda, ralhando por trovões, carbonizando meninos com o corisco. Eu aprendera a ler pelos livros elementares de Aristarco, e o supunha velho como o primeiro, porém rapado, de cara chupada, pedagógica, óculos apocalípticos, carapuça negra de borla, fanhoso, onipotente e mau, com uma das mãos para trás escondendo a palmatória e doutrinando à humanidade o b-a-bá. As impressões recentes derrogavam o meu Aristarco [...] Dava-me gosto então a peleja renhida das duas imagens e aquela complicação imediata do paletot de seda e do sapato raso, fazendo aliança com Aristarco II contra Aristarco I, no reino da fantasia. (OA, p. 46)

Apesar de paternal, à primeira vista, Aristarco é visto como empresário em férias, cujo espírito e sentimento se traduzem em "padrões" e "faturas", mesmo quando de paletó de seda e "calçado raso". Curiosamente, é a informalidade que preocupa e espanta Sérgio, que esperava ver aquele pelo qual entendia ser o diretor, e não ele próprio. Conquanto tenha aprendido a ler e escrever com os métodos do pedagogo, o menino não demonstra sinais de agradecimento (como faria supor sua conduta, até o momento, de bom menino e bom aluno), mas prevê no autor dos livros didáticos um ente apocalíptico e de esfera transcendente, imediato após "Nosso Senhor" na punição e correção dos jovens (tal como numa versão invertida, mas linear, do discurso de Venâncio). O menino não sabe como reagir à derrocada de seu "alto" ideal, que, assim, não demonstra ser de ordem elevada como se faria supor - uma educação moralmente

resistência, mesmo quando a intersecção se dê fora de um contexto de militância política. Raul Pompéia, no Ateneu, fez ora sátira direta, ora paródia, da linguagem pedagógica e da retórica científica e literária predominante nas escolas para a elite de nosso Segundo Império". Para um aprofundamento maior dos sentidos satíricos e paródicos do romance, $c f$. o estudo de Sônia Brayner (1979). 
esmerada, com mestres dignos e alunos comprometidos etc. -, mas tão somente o decoro das circunstâncias - o garbo das solenidades, do mestre fisicamente irreprochável etc. Nada se diz acerca do mérito de Aristarco como pedagogo, tampouco da escolha de seu instituto pelo pai - provavelmente motivada pelo sucesso de seus métodos na alfabetização do filho; o que perdura na memória é a desilusão (um pouco arrogante) do menino.

De maneira ainda mais incisiva, o narrador destaca a seguir o desajuste entre essas duas imagens (imagens, e não pessoas, nos termos mais epidérmicos de Sérgio) "no reino da fantasia", contrapondo a Aristarco I, ser apocalíptico que lhe bastava como “o meu Aristarco", Aristarco II, ser de carne e osso, a recepcioná-lo ao colégio, via residência. Quiçá nessa mediação do plano doméstico ao público esteja a pedra de toque das desconfianças do menino, que pensava ser o internato um mundo inteiramente diverso daquele vivido até então, e que, de todo, não o era, e nem podia sê-lo.

Curiosamente, quando da segunda entrevista com Aristarco, na ocasião da despedida do pai, o diretor é visto como gerente de sua instituição, desprovido de qualquer ranço paternal, o que desorienta o menino e como que prevê boa parte de sua estadia no Ateneu, até os encontros subsequentes com o pai, já fora do colégio:

O diretor, no escritório do estabelecimento, ocupava uma cadeira rotativa junto à mesa de trabalho. Sobre a mesa um grande livro abriase em colunas maciças de escrituração e linhas encarnadas. Aristarco, que consagrava as manhãs ao governo financeiro do colégio, conferia, analisava os assentamentos do guarda-livros. De momento a momento, entravam alunos. Alguns acompanhados. A cada entrada, o diretor lentamente fechava o livro comercial, marcando a página com um alfanje de marfim, fazia girar a cadeira e soltava interjeições de acolhimento, oferecendo episcopalmente a mão peluda ao beijo contrito e filial dos meninos. Os maiores, em regra, recusavam-se à cerimônia e partiam com um simples aperto de mão. (OA, p. 51)

Representado não em suas funções didáticas, mas burocráticas, Aristarco agora é visto antes como gerente que como educador: sua mesa de trabalho permite entrever detalhadamente um "livro de escrituração", que resume e antecipa a entrada dos alunos, ditada pela condição financeira dos pais e pelo balanço favorável ou não das matrículas. A recepção dos internos, especialmente dos ingressantes, reserva-lhe assim um não lugar de "Relações Públicas", embora magistralmente desempenhado, pois, como diz Sérgio a seguir, "[o diretor] punha habilmente um sujeito fora de portas com o riso fanhoso e o simples modo impelido de segurar-lhe os dedos." (OA, p. 53) A superioridade do diretor ante pais e alunos é comprovada pela destreza com que passa 
de uma atitude a outra, o que, em seu dinamismo, implica dois elementos que se não podem destacar: a ambiguidade (do educador) e a especulação (do administrador).

Ambiguidade é o que se pode tomar de seu acolhimento por vezes exagerado dos meninos, em que pontifica, à revelia das comparações anteriores de Venâncio e do próprio Sérgio, com uma autoridade tanto religiosa (mão "episcopalmente" oferecida a beijar) quanto secular (beijo "filial” recebido), sem a qual - e é o que se percebe no caso dos internos mais crescidos - todo cumprimento descai em formalidades ("simples aperto de mão"). Ou seja, e é o que narrador talvez queira apontar, a autoridade do diretor não tem fundamento real, e, para causar uma primeira e forte impressão, depende de tomar de empréstimo à relação pai-filho apenas a exterioridade respeitosa, sem o elo de sangue (ou, ao menos, de convívio e camaradagem) pressuposto. Aristarco, apesar das aparências, vive dos alunos, explorando-os de forma material, mas não convive com eles, o que constitui, até certo ponto (e certamente para Sérgio protagonista), uma exploração paralela, digamos, de ordem moral.

Por outro lado, essa dupla especulação, que atinge a essência do cotidiano dos meninos, fora e (já) dentro do internato, confirma-se no trecho imediatamente a seguir: "O especulador e o levita ficavam-lhe dentro em camaradagem íntima, bras dessus, bras dessous. Sabiam, sem prejuízo da oportunidade, aparecer por alternativa ou simultaneamente; eram como duas almas inconhas num só corpo. Soldavam-se nele o educador e o empresário com uma perfeição rigorosa de acordo, dois lados da mesma medalha; opostos, mas justapostos." (idem).

Para descrever o diretor, e logo traduzindo aqueles termos de ambiguidade e especulação, o narrador cunha a metáfora da "medalha". Todavia, apesar de soar como uma dupla significação, pela evidência dos dois lados que a compõem, ela traduz apenas em parte a personalidade de Aristarco, pois privilegia claramente uma das faces que busca representar. Se, de um lado, Sérgio inscreve um pedagogo renomado (ainda que aparentado, ainda há pouco, a um ente apocalíptico), por outro, o empresário é gravado em seu próprio ambiente e material. Trata-se de dois lados de uma mesma "medalha", objeto cunhado com fins de mérito e de renome, e que simboliza caracteristicamente os objetivos de um Aristarco "especulador", mas nada de um outro Aristarco "levita", que se basta apenas a completar a ideia de "duas almas inconhas num só corpo". ${ }^{9}$ Não há

\footnotetext{
${ }^{9}$ É curioso notarmos que na passagem Sérgio não se valha, em vez da figura da medalha, daquela da moeda: ultrapassando seu valor material evidente, seu objetivo é ressaltar o absurdo de sua falsidade moral traduzido nos termos dessa mesma materialidade.
} 
nada dialético na imagem empregada, mas somente a sobreposição de constatações cruas; de qualquer forma, reforçar sua incompatibilidade ou "hipostasiar o termo "dialética" significa precisamente revelar sua total ausência no mundo do Ateneu." (MAZZARI, 2010, p. 190). Logo, e para retomarmos generalidades a esta altura evidentes, a "medalha" resume a ânsia do diretor pela fama rasteira e imediata (material, moral), e não pela transcendência dos valores que deveria pregar como educador. Sua mera existência torna-se um disparate e, possivelmente, uma heresia: do ponto de vista educacional, por antepor a consequência à causa (retorno financeiro à qualidade de ensino); e do ponto de vista humano e religioso, por deturpar sua origem como forma de justificar a existência (duas almas como álibi da falsidade). Aristarco resume-se, tal como a medalha, a um ornamento de si mesmo e de seu colégio, e, enquanto tal, dispensa comentários pelo grotesco da comparação, que salta como que "forçada" aos olhos do leitor, justamente pela ênfase excessiva numa formalização total do ensino impulsionada, num sentido mais pontuado e "memorialístico", pela separação entre Sérgio e seu pai.

Sérgio recusa-se a ver no diretor o afeto que recebe do pai; para ele, o ensino resume-se a uma relação comercial, entre estranhos, e jamais afetiva, entre parentes ou amigos. De fato, como afirma o narrador, seu próprio pai treme ante as ameaças de Aristarco: "Afianço-lhes que o meu [pai] tremeu por mim. Eu, encolhido, fazia em superlativo a metáfora sabida das varas verdes”. (OA, p. 56) O que faz apenas crescer o sentimento iminente de desconsolo, por parte do protagonista: se seu pai, que era adulto e estava ciente da luta que (con)figura o mundo adulto, tremia por si, quem dirá então (e o apelo ao leitor é pontual nesse aspecto) de um menino de onze anos?

Os termos do diretor, de fato, são peremptórios contra toda espécie de infração às regras de seu colégio, que, antes da má conduta em sala ou nos estudos, preocupa-se com a formação moral dos meninos: "O parricídio não figurava na lei grega. Aqui não está a imoralidade. Se a desgraça ocorre, a justiça é o meu terror e a lei é o meu arbítrio." (idem). O terror imprime-se sobre Sérgio e seu pai, pois ambos acabam, pelo discurso de Aristarco, destituídos de sua zona de conforto; Sérgio, pela necessidade de responder agora a "dois pais" com a mesma submissão dantes; e o pai, pela substituição de sua figura de mando por um código de conduta que vale, a um tempo, como estatuto da instituição e como tutor (genitor) da vida moral dos internos/filhos.

A inversão dos lugares sociais e familiares logo se traduz no arremate de Aristarco à apresentação - "Mas para os rapazes dignos eu sou um pai” (idem) -, que 
pouco impressiona ao menino, já acostumado a acatar máximas desse jaez. Pois, segundo o narrador, os diversos quadros do Ateneu "exibiam sonoramente regras morais e conselhos muito meus conhecidos de amor à verdade, aos pais, e temor de Deus, que estranhei como um código de redundância.” (OA, p. 55) A ordem dos elementos é importante, e indica o quanto o narrador aproxima a figura paterna da "verdade" primordial, antes mesmo do "temor de Deus", num movimento de enfado ou "redundância" que bem caracteriza sua comodidade na presença do pai.

A tranquilidade de Sérgio dentro em pouco iria acabar, muito embora, à hora da despedida, conseguisse segurar as lágrimas "a tempo de ser forte" (OA, p. 56). A solidão dentro do deserto do internato logo mostraria ser, como o pai predissera, um tempo de provação:

Era o ermo. E na solidão conspiradas, as adversidades de toda a espécie, falsidade traiçoeira dos afetos, perseguição da malevolência, espionagem da vigilância; por cima de tudo, céu dos trovões sobre os desalentos, a fúria tonante de Júpiter-diretor, o tremendo Aristarco dos momentos graves.

Lembranças da família desviaram-me o curso às reflexões. Não havia mais a mão querida para acalentar-me o primeiro sono, nem a oração, tão longe nesse momento, que me protegia a noite como um dossel de amor: o abandono das crianças sem lar que os asilos da miséria recolhem. (OA, p. 69)

\section{"As fisionomias do caráter"}

O primeiro ano no Ateneu não transcorre sem a constante visita do pai, que, no entanto, pouco sabe do que se passa com Sérgio: "Meu pai vinha ver-me todas as semanas; eu mostrava os prêmios de aplicação, conversava de casa; o resto calava." (OA, p. 88). Ocultando do pai as pressões homossexuais de Sanches, os conselhos violentos de Rabelo, as agressões de Barbalho etc., que constituem o grosso de suas memórias até então, parece que tudo se lhe transcorre como num hiato, sem a devida importância para sua formação, permanecendo "como um corpo estranho" no internato (MIGUEL-PEREIRA, 1973, p. 112); do contrário, informaria ao pai imediatamente.

É quando as pressões externas começam a incomodar demasiadamente que Sérgio retorna ao lar, na ocasião de um feriado, e encontra, por fim, a constituição do caráter nas esperadas confidências ao pai. A primeira descrição do retorno é traduzida nos termos de uma ressurreição: "Quando tornei a ver os meus, foi como se os houvesse adquirido de uma ressurreição milagrosa. Entrei em casa desfeito em pranto, dominado pela exuberância de uma alegria mortal." (OA, p. 123) Assim, a saída da "placenta" do espaço doméstico para o contato com o mundo, via internato, faz morrer o indivíduo, e o retorno pelo caminho inverso, dá-lhe a chance milagrosa de uma nova vida, concedida 
diretamente por Deus: "Deus permitira, na largueza pródiga da suma bondade, que eu revisse a nossa casa [...] e a chaminé tranquila a fumar o spleen infinito das cousas imóveis e elevadas." (OA, p. 124) Longe do Ateneu e das diversas ameaças dos colegas e professores, Sérgio pode respirar a atmosfera pacata do lar, cujo conforto lhe inspira o extravasamento das emoções:

Ia efetivamente ruminando a mais séria das intenções: afrontar uma entrevista franca com meu pai, descrever-lhe corajosamente a minha situação no colégio e obter um auxílio para reagir.

Meu pai acabava de deixar o leito. Nada sabia dos meus últimos insucessos. Ficou admirado e consternado. Daí o êxito completo da minha entrevista.

Dias depois, no colégio, eu era um pequeno potentado. [...] Um conselho de casa afirmou-me que havia a nobre opinião de Aristarco e a opinião ainda melhor da cartilha, mas havia uma terceira - a minha própria, que se não era tão boa, tão abalizada como as outras, tinha a vantagem alta da originalidade. Com uma palavra fez-se um anarquista.

Daí por diante era fatal o conflito entre a independência e a autoridade. Aristarco tinha de roer. (OA, p. 124-125)

Destaquemos a importância central deste "conselho de casa", obtido com a entrevista do pai, que acarreta uma importante inversão dos papeis aluno x professor. $\mathrm{Na}$ superfície, o conselho paterno é, além de válido, irreprochável, pois enfatiza a autoconfiança do menino nas próprias forças, bem como naquilo que elas podem ter de “original". Todavia, a ordem dos fatores altera o produto, e a adversativa com que é apresentada a proposição diminui o papel de dois elementos até então intocados pelo pai: a figura do mestre e, acima dele, a mecânica do ensino institucionalizado. Em prol da autonomia do menino, desbancam-se a autoridade do mestre - e junto com ela, a do pai postiço, que se lhe entranhara desde as primeiras apresentações e entrevistas - e a validade especular das notas, no tocante à formação do menino. Seu caráter já está formado - é o que o pai lhe garante -, e frente à inadaptação ao meio escolar, basta voltar aos códigos do lar, em que Sérgio, filho único e adorado, é irretocável (original). Problema resolvido.

Duas contradições, a contrapelo daquilo que diz o pai e faz o filho, vão pari passu com a cena acima. A primeira diz respeito ao tiro no próprio pé que desfere o pai ao desmerecer a figura de Aristarco, misto de educador e pai, para quem os bons alunos são como filhos. O silogismo é simples, mas claramente falho: Sérgio não é bom aluno; Aristarco não se lhe porta como pai; logo: Aristarco não é dono exclusivo da verdade. $O$ que não se pode prever, a partir desse argumento, é a extensão da rebeldia do menino, 
possivelmente desfavorável ao próprio pai, enquanto figura de mando. Como Sérgio destaca, sua admiração e consternação são decisivas para o sucesso da entrevista. ${ }^{10}$

A segunda contradição é mais óbvia, e diz respeito ao conteúdo do conselho, impossibilitado pela ocasião mesma em que é proferido. O conselho versa sobre a originalidade do filho, superior a tudo... mas continua sendo um conselho, e segui-lo, é desmentir aquilo mesmo que aponta. Como ser original, obedecendo cegamente a um preceito, seja ele qual for? Claramente, a originalidade em questão é endereçada, e visa sobrepor à escola o discurso do pai, tendo em vista as dificuldades de Sérgio. Original equivale a ser igual ao pai; o que já é ser diferente, para todos os efeitos, daqueles do colégio, e basta para solucionar os problemas do menino.

Os efeitos do conselho sobre Sérgio são devastadores. Imediatamente a seguir, conquista para si a inimizade de todos, fazendo-se arbitrário e displicente:

Para a campanha da reação, armazenei uma abastança inextinguível de vaidade e deliberei menosprezar do melhor modo prêmios e aplausos com que se diplomavam os grandes estudantes. [...] Desenvolveu-se nas alturas uma forma de antipatia contra mim que me lisonjeava como uma das formas da consideração. [...] Eu sorria vaidoso, levando de vencida a guerrinha, como a espuma à proa de um barco.

Este foi o caráter que mantive, depois de tão várias oscilações. Porque parece que às fisionomias do caráter chegamos por tentativas, semelhante a um estatuário que amoldasse a carne no próprio rosto, segundo a plástica de um ideal; ou porque a individualidade moral a manifestar-se, ensaia primeiro o vestuário no sortimento psicológico das manifestações possíveis. (OA, p. 125-126)

As desavenças anteriores à entrevista - os espectros de Aristarco, Sanches, Rabelo, Barbalho, Franco etc. - resumem-se ao ensaio dos primeiros vestuários da personalidade, exterior e dispensável; acima das roupas, ergue-se o rosto esculpido pelo ideal, absoluto... A posição de Sérgio é, assim, clara: o caráter que se deveria manter para a fase adulta não seria aquele aprendido na luta com o Ateneu, mas aquele trazido de casa, ideal que se lhe amolda no próprio rosto e dita a fisionomia. Vemos que não se cogita a individualidade do mesmo, apesar da exterioridade do processo, e da submissão a ele: "original", o menino basta-se como filho de seu pai. É curioso notarmos que na etimologia de seu nome, tal acepção conservadora está desde sempre presente - "Serg-"

\footnotetext{
${ }^{10}$ Entrevista que constitui, tal como na lógica tripartite do conselho paterno, a terceira do romance, precedida somente pelas duas de Aristarco (em sua casa e no Ateneu). O paralelo é evidente: a primeira foi promissora, a segunda ainda melhor; mas a terceira...
} 
significa "servo, o que cuida, protege" (GUÉRIOS, 1981, p. 225), ${ }^{11}$ estabelecendo como paradigma de compreensão do narrador seu caráter contraditório de menino obediente (ao pai) e rebelde (à escola), como que a defender um discurso em detrimento do outro, talvez mesmo pela premência deste face à obsolescência daquele.

Quanto ao comportamento dentro do Ateneu, que irá dar continuidade às memórias do adulto, "nesse momento ele atinge uma posição definida [e já pressuposta por sua posição “definitiva”]. [...] Diante da disciplina, Sérgio cresce em compreensão e desencantamento. Crescer é, assim, indisciplinar-se.” (HOSIASSON, 1988, p. 78)

\section{A cristalização do caráter}

Após o transcorrer do primeiro ano no Ateneu, guiado pelas considerações acima a despreocupar-se dos estudos, a deleitar-se com o espetáculo do assassinato e com as formas de Ângela, a aproveitar-se da ingenuidade de colegas como Bento Alves, a zombar das exposições vazias e verborrágicas do "Grêmio Literário Amor ao Saber" etc., Sérgio dispõe de dois meses em casa para observar o movimento da sociedade fora do colégio. Durante esse período, cristaliza-se a crença nas próprias forças, apreendida dos conselhos paternos, ao ponto de compreender-se superior não apenas ao universo do colégio, mas também àquele fora dele e do espaço doméstico:

Desenvolvido à força e habilitado no torvelinho moral do internato,
aproveitara os dois meses de feriado para espreitar a animação da vida
exterior. A sala, a sociedade, os negócios da praça pública, que na
infância são como contactos de nevoeiros resvalando pela imaginação
[...], ao tempo em que preferimos da soirée os bons bocados, das
toilettes os laços de cores rútilas, ignorando que há talvez na vida
alguma cousa mais açúcar que o açúcar, e que o toque macio pode
uma vez levar vantagem à coloração fulgurante, quando invejamos das
posições sociais modestamente o garbo de Faetonte nos carros de
praça ou a bravura rubente de umas calças de grande uniforme, sem
saber que as ambições vão mais alto e que há comendadores; o
movimento do grande mundo não me aparecia mais como um teatro
de sombras. (OA, p. 189)

A evolução do pensamento de Sérgio é marcante; para além do garbo imediato das fardas de uma parada militar, postiço e convencional (como aquele das festas do colégio), está algo "mais açúcar do que o açúcar”, e que é a glória - não menos superficial, embora certamente mais aceite - das "ambições [que vão] mais alto": as

${ }^{11}$ Por oposição a Aristarco: "Aristo-" designa "excelente, o melhor", enquanto "-arco" indica "o que conduz, guia, chefe, o mais poderoso" (HOUAISS, 2001, p. 278, 288). Consequentemente, ao poderoso e excelente chefe na aparência, sucede um servo moralmente superior. 
comendas, os altos cargos burocráticos, o luxo que não se deixa limitar às paredes de um mero internato. Pulando uma etapa importante de sua formação, Sérgio não se preocupa tanto com o aproveitamento escolar ou acadêmico que possa ter (desmerecido pelo pai); o que se lhe projeta no futuro é a glória social, a posição de mando e de destaque de um comendador, ou ainda de um deputado, um ministro... Ou ainda, a vitória de uma conquista amorosa, entrevendo por detrás do rubro do vestuário o rubor das formas (como o jambo das pernas de Ema, mulher de Aristarco). Tanto lá quanto cá, trata-se de duas formas distintas, mas convergentes, de autossatisfação, nos termos sempre reiterados de seu pai: aquela que cuida do Sérgio social, representante de sua classe, almejando alcançar um posto de destaque e tornar-se um dos figurões do Império; e aquela que cuida do Sérgio pessoal, "conquistador" num sentido mais chão, buscando prazeres imediatos os mais diversos. ${ }^{12}$

Reconhecendo a semelhança entre o colégio e a sociedade, todavia, no tocante à postura de si exigida, Sérgio destaca precisamente a continuidade e evolução de seu pensamento neste sentido: "Comecei a penetrar a realidade exterior como palpara a verdade da existência no colégio.” (idem). Porém, a amplitude de suas ambições destoa claramente daquilo que poderia esperar um aluno de 12 anos, e não é sem pesar que diz a seguir: "Desesperava-me então ver-me duplamente algemado à contingência de ser irremissivelmente pequeno ainda e colegial. Colegial, quase calceta! marcado com um número, escravo dos limites da casa e do despotismo da administração.” (OA, p. 190) O termo é incisivo: o cotidiano de um colegial equivale, "quase", ao de um "calceta", um escravo. Assim, na hierarquia que se apresenta, o ápice toca aos comendadores e a base aos escravos, estando, pouco acima do rés-do-chão, os alunos, visão invertida que se recusa a observar a formação individual propiciada pelos estudos. Ao contrário, os mesmos estudos parecem impedir que o jovem se integre às altas rodas, descaracterizando-o, marcando-o "por um número".

O segundo ano letivo transcorre sob o "despotismo da administração", despertando novas animosidades de Sérgio, a ponto de eclodir um conflito direto entre o menino e o velho diretor. Todavia, não há a mesma compensação das férias

${ }^{12}$ Uma leitura oposta pode ser encontrada em Jubran (1980, p. 180-181): “A não-realização das aspirações infantis cria, portanto, na obra, a invariante decepção, como resíduo de toda e qualquer experiência de vida. E a recorrência dessa invariante encontra expressão na imagem da 'enfiada de decepções', que traduz a acumulação de desenganos na sucessividade do tempo, e a consequente ligação do presente do narrador ao passado da personagem." Assim, ao que entendemos pelo que seria uma "invariante satisfação", posta-se a sugestão da autora de uma "invariante decepção", tendo como ponto de partida para a comparação não o olhar do narrador adulto, mas o do protagonista menino. 
prolongadas, visto que o protagonista adoece, acometido de sarampo, e tem de ficar na enfermaria do Ateneu, sob os cuidados de Ema. Curiosamente, não apenas o menino, mas também seu pai, cai enfermo, sendo levado às pressas à Europa. De lá - ou mais precisamente, de Paris -, envia ao filho uma carta que, sozinha, praticamente resume o sentido temporal e social do romance, mesclando à importância da ação direta sobre o passado a origem dúbia da enfermidade de ambos.

Observemos a carta, na íntegra, apesar de sua extensão um pouco prolongada:

"Salvar o momento presente. A regra moral é a mesma da atividade. Nada para amanhã, do que pode ser hoje; salvar o presente. Nada mais preocupe. O futuro é corruptor, o passado é dissolvente, só a atualidade é forte. Saudade, uma cobardia, apreensão outra cobardia. O dia de amanhã transige; o passado entristece e a tristeza afrouxa.

Saudade, apreensão, esperança, vãos fantasmas, projeções inanes de miragem; vive apenas o instante atual e transitório. É salvá-lo! salvar o náufrago do tempo.

Quanto à linha de conduta: para diante. É a honesta lógica das ações.

Para diante, na linha do dever é o mesmo que para cima. Em geral, a despesa do heroísmo é nenhuma. Pensa nisto. Para que a mentira prevaleça é mister um sistema completo de mentiras harmônicas. Não mentir é simples.

... Estou numa grande cidade, interessante, movimentada. As casas são mais altas que lá; em compensação, os tetos mais baixos. Dir-se-ia que o andar de cima esmaga-nos. E como cada um tem sobre a cabeça um vizinho mais pobre, parece que a opressão, aqui, pesa da miséria sobre os ricos.

A agitação não me faz bem.

Abro a janela para o boulevard: uma efervescência de animação, de ruído, de povo, a festa iluminada dos negócios, das tentativas, das fortunas... Mas todos vêm, passam diante de mim, afastam-se, desaparecem. Que espetáculo para um doente! Parece que é a vida que foge.

Dou-te a minha benção..." (OA, p. 263)

A enfermidade de Sérgio explica-se, para além da óbvia recaída física, pelo ambiente adverso do Ateneu, pelas horas passadas longe da Corte, pelas ambições de menino-homem... E quanto à enfermidade do pai? Direto de Paris, o conselho que envia ao filho já não versa sobre a necessidade de reconhecer o próprio valor, mas sobre a importância da ação - e não do pensamento - presente. Mais que o futuro, tempo reservado para as vicissitudes da opinião alheia, que pode (des)motivar o menino a agir; mais que o passado, tempo reservado para a autocomiseração retrospectiva, impotente quanto à atual revisão dos fatos e endereçada unicamente para a conservação de eventos que não mais interferem imediatamente no curso dos demais: trata-se de "salvar o momento presente", ou, em termos narrativos (que tocam mais de perto ao Sérgio adulto), o próprio presente da narração, o instante atual e fugaz da recriação do passado pela memória, que (re)codifica o sentido de outrora segundo os interesses sempre 
atualizados do memorialista, a preencher as lacunas da vida transcorrida no instante mesmo em que a revisita. Antevendo sabiamente aquilo que separaria o homem do menino, o pai indica o caminho que, mais tarde, deveria trilhar ao considerar o período de "formação" - o balanço parcialmente imparcial dos fatos, traduzido como "Crônica de saudades", subtítulo que encerra uma contradição prevista pela estratégia da argumentação paterna.

De um ponto de vista teórico-contextual, "a alma que anima as crônicas é [...] a que animava as praças onde se reuniam, em magotes ou em assembleias, os homens das vilas" medievais, e nessa primeira acepção do termo "a voz popular, a opinião pública, tem um papel funcional", estabelecendo aí um registro histórico basicamente cronológico de eventos importantes para a história de um povo (Saraiva, 1997, p. 27). Seguindo essa definição, a escrita de uma crônica "de saudades" somente poderia indicar um contrassenso: como afirmar que eventos de ordem puramente pessoal sejam de interesse público? Ou então, como sustentar a possibilidade de um relato cronológico de dados subjetivos, orientados para a apreciação positiva de uma só experiência de vida? ${ }^{13}$

A explicação é simples e decisiva: "a regra moral é a mesma da atividade." Ou seja, não há que pensar num plano teórico ou mesmo pragmático sobre essa centralidade contraditória do presente de um indivíduo, desconsiderando-se a validade da inserção coletiva de suas memórias pessoais; pois o que quer que seja feito pela decisão de Sérgio, de uma forma ou de outra "atual", é asseguradamente o quanto basta. "Nada mais preocupe." Em outras palavras, o pai concede ao filho carta branca para fazer aquilo que bem entender em sua ausência (tal qual o branco das páginas em que é escrito $O$ Ateneu); herdeiro legítimo, substituto imediato de seu nome, na eventualidade de uma tragédia que possa advir de sua doença, que faça o que bem entender. $\mathrm{E}$ "saudade" não é um termo que possa entrar demasiado no vocabulário do narrador, tendo em vista os conselhos paternos; "saudade, apreensão, esperança" não passam de "vãos fantasmas, projeções inanes de miragem". Então, o que pretende Sérgio ao tecer sua "Crônica de saudades"?

A continuidade da carta vai esclarecendo, pouco a pouco, as perguntas que ficam em aberto. Dando seguimento à lógica peremptória e arrogante do "tudo-pode", prevista nas primeiras linhas, o pai afirma a seguir que "não mentir é simples." Óbvio, posto que

\footnotetext{
${ }^{13}$ Para um histórico do conceito e um levantamento de seus principais sentidos, cf. Coutinho (1982).
} 
tudo que for dito seja (e é) forçosamente verdade individual e "presente". Observemos, não obstante, o trecho narrativo posterior. De acordo com o remetente, a cidade em que se encontra, Paris, é grande e movimentada, parecendo-lhe opressiva inclusive em sua arquitetura - os tetos são mais baixos. O que lhe desperta a atenção, todavia, é que "como cada um tem sobre a cabeça um vizinho mais pobre, parece que a opressão, aqui [por oposição à referência comum do Rio de Janeiro], pesa da miséria sobre os ricos.”

Ora, coloquemos o que há de comum nas duas situações. Sérgio está doente, como seu pai. Sérgio enfrenta um ambiente opressivo, o internato, que se lhe afigura como uma das causas do agravamento da doença, praticamente impossível num ambiente de recato e de cuidado como o lar (sabe-se que está acometido do contágio do sarampo); o pai, levado às pressas para a Europa, encontra um ambiente muito mais desenvolvido que o seu, onde a estagnação, causa, porém, da falta de médicos capacitados, servia-lhe de certa forma como bálsamo para seu estado febril e convalescente. Em ambos os cenários, temos um indivíduo fora do meio que lhe diz respeito, e que transcende suas capacidades de defesa: Sérgio no internato, o pai em Paris. Tendo em vista que, no futuro, Sérgio há de vir a ocupar o nome e, ao que tudo indica, a posição social privilegiada do progenitor, há de enfrentar a mesma inferioridade face àquele segundo Ateneu, mundo mais amplo do que pode conhecer (e combater). Coexistem, pois, duas lutas paralelas: a de Sérgio com o internato; e a do pai com a doença, ou melhor, com a diferença dos meios europeu e brasileiro, que se traduz (observemos novamente o padrão de comparação) pela relação de opressão entre as classes - no Brasil, dos ricos sobre os pobres; e em Paris, dos pobres sobre os ricos (pelo menos, sobre os rastaqueras do Novo Mundo, a esbanjar o que não são ou possuem, exigindo uma atenção que não lhes é devida). É sabido, diga-se de passagem, que as modernizações do Barão Haussmann na capital francesa fizeram confluir para o centro da cidade uma grande densidade demográfica, gerando uma especulação imobiliária que, ironicamente, fazia multiplicarem os aluguéis de sótãos e de cômodos superiores pelos proprietários (pressão relativa, assim, "da miséria sobre os ricos", na "Île de France"). ${ }^{14}$

O ponto de toque da carta é, consequentemente, social, e diz respeito a relações de poder. O que poderá, então, significar o conselho do pai - "salvar o momento presente" - sob o prisma indicado, senão prevenir que o mesmo aconteça no Brasil?

\footnotetext{
${ }^{14}$ Cf. a este respeito a discussão modelar de Eric Hobsbawm (2007, p. 147-193), assim como os
} apontamentos contextuais de Meyer Schapiro (2002, p. 160-194) e Peter Feist (2006, p. 9-31). 
Traduzindo, a contrapelo, as palavras da carta, teremos algo como: "faça o que fizer, mantenha a posição e saiba de onde fala. Não deixe que te desprezem ou diminuam; faça-o você, antes que o façam." A tradução é meramente alusiva, mas parece vir a bom tempo quando retomadas as últimas palavras do pai: “Que espetáculo para um doente! Parece que é a vida que foge... Dou-te a minha benção." Vida, nos termos em questão, parece corresponder justamente ao destaque social em meio à multidão que passa, e que desconhece a importância daquele brasileiro tão importante em sua terra, mas ali, insignificante. A experiência da multidão, impossível num ambiente retraído como o da Corte ${ }^{15}$ representa até certo ponto a extensão do drama do pai de Sérgio: ali, ele é mais um, tal como filho, "marcado com um número", com a única diferença de ser escravo não daquele reiterado "despotismo da administração", mas da força das circunstâncias. Tanto em um caso quanto noutro, está claro que a regra moral não pode ser a mesma da atividade; a regra moral ultrapassa, por definição, as ações individuais. ${ }^{16}$

\section{Conclusão: o discurso paterno em retrospecto}

Considerado em sua totalidade, os diversos momentos de aparecimento do discurso paterno através daquele do narrador demarcam os pontos de divisão da obra. Aparentemente dividida de acordo com um critério cronológico - e que diz respeito ao ingresso no internato (capítulo 1), primeiro ano letivo (capítulos II a VII), segundo ano letivo (VIII a XI), incêndio do Ateneu (capítulo XII) (REIS, 1976) -, ela coincide com a interação entre pai e filho, conforme expusemos mais acima, em suas diferentes fases. Primeiramente, na convivência completa entre pai e filho no recato do lar, sucedida pelas primeiras visitas, um em companhia do outro, ao Ateneu (capítulo I); a seguir, na separação e no retorno a casa, com os conselhos decisivos do pai para as dificuldades encontradas pelo filho (intervalo do capítulo II ao VII, em que o conselho aparece no

\footnotetext{
${ }^{15}$ Principalmente, tendo em vista a posição de Sérgio como letrado, do ponto de vista cultural-intelectual. Segundo dados expostos por Hélio de Seixas Guimarães (2004, p. 62-66), enquanto em 1878 a França e a Inglaterra contavam com $77 \%$ e $70 \%$, respectivamente, de população alfabetizada, havia em 1872 apenas $15,7 \%$ de alfabetizados no Brasil; $18,6 \%$ se considerados apenas os homens livres.

${ }^{16}$ Não parece despropositado remetermos aqui ao "imperativo categórico" de Kant na Fundamentação da metafísica dos costumes. Como expõe o filósofo alemão, o que distingue a lei moral de uma máxima moral, como a de Sérgio, é o princípio objetivo, e não subjetivo do querer; i.e., todo dever "é a necessidade de uma ação por respeito à lei [moral]." (KANT, 1995, p. 38) Neste sentido, a fórmula de determinação moral capaz de objetivar uma ação necessária por si mesma é: "Age apenas segundo uma máxima tal que possas ao mesmo tempo querer que ela se torne lei universal." (idem, p. 59, grifos do autor) Precisamente, é o oposto do universal que interessa a Sérgio - fazer de sua própria ação (individual) a regra da moralidade (coletiva), inversão abominável do ponto de vista kantiano.
} 
capítulo V, intitulado muito a propósito "Rebote"); nas férias de fim de ano, quando retorna ao espaço doméstico e amadurece a visão paterna da sociedade (ocorrida no capítulo VII); e, finalmente, na leitura atenta e, para todos os efeitos, significativa, da carta do pai, enviada da Europa (capítulo XII, imediatamente anterior ao incêndio do Ateneu).

Se considerarmos a gravidade do conselho paterno, e a obediência servil do filho (prevista, como mencionado mais atrás, desde a etimologia de seu nome), notaremos que o incêndio do internato, na recriação do passado, não aparece sem propósito justamente poucas páginas depois do recebimento da carta: "Momento presente... Eu tinha ainda contra a face a mão que me dera a carta; contra a face, contra os lábios, venturosamente, ardentemente, como se fosse aquilo o momento, como se bebesse na linda concha da palma o gesto imortal da viva verdade.” (OA, p. 263-264)

Enfim, e para todos os efeitos, Sérgio é o filho de seu pai.

\section{Referências}

ABDALA Jr., Benjamin; CAMPEDELLI, S.Y. Raul Pompéia. In: Tempos da literatura brasileira. 6 ed. São Paulo: Ática, 1999. p. 149-153.

BOSI, Alfredo. Literatura e resistência. São Paulo: Companhia das Letras, 2002.

BRAYNER, Sonia. Raul Pompéia e a aprendizagem do Mal. In: Labirinto do espaço romanesco: tradição e renovação da literatura brasileira 1880-1920. Rio de Janeiro: Civilização Brasileira; Brasília: INL, 1979. p. 119-145.

CAPAZ, Camil. Raul Pompéia: biografia. Rio de Janeiro: Gryphus, 2001.

CHAVES, Flávio Loureiro. O "traidor" Raul Pompéia. In: O brinquedo absurdo. São Paulo: Polis, 1978. p. 49-76.

COUTINHO, Afrânio. Introdução. In: (Org.). Obras de Raul Pompéia: crônicas I. Organização e notas de Afrânio Coutinho. Rio de Janeiro: Civilização Brasileira; MEC; FENAME; OLAC, 1982. v.6. p. 13-36.

FEIST, Peter. O impressionismo em França. In: WALTHER, Ingo (Dir). A pintura impressionista: 1860-1920. Cingapura: Taschen, 2006.

GOMES, Eugênio. Um inédito de Raul Pompéia. In: Prata da casa: ensaios de literatura brasileira. Rio de Janeiro: A Noite, 1953. p. 113-116.

GUÉRIOS, Rosário Farâni Mansur. Dicionário etimológico de nomes e sobrenomes. 3 ed. São Paulo: Ave-Maria, 1981.

GUIMARÃES, Hélio de Seixas. Os leitores de Machado de Assis: o romance machadiano e o público de literatura no século XIX. São Paulo: Nankin; EDUSP, 2004.

HOBSBAWM, Eric. A era do capital: 1848-1875. 13 ed. São Paulo: Paz e Terra, 2007. 
HOSIASSON, Laura. Disciplinas e indisciplinas no Ateneu. In: PERRONE-MOISÉS, Leyla (Org.). O Ateneu: retórica e paixão. São Paulo: Brasiliense; EDUSP, 1988. p. 6878

HOUAISS, Antonio; VILLAR, Mauro de Salles. Grande dicionário Houaiss da língua portuguesa. Rio de Janeiro: Objetiva, 2001.

JUBRAN, Clélia Cândia Abreu Spinardi. A poética narrativa de O Ateneu. São Paulo: FFLCH, 1980. Tese de Doutorado.

KANT, Immanuel. Fundamentação da metafísica dos costumes. Trad. Paulo Quintela. Porto: Porto Editora, 1995.

MAZZARI, Marcus Vinicius. "Um ABC do terror”: representações literárias da escola. In: L Labirintos da aprendizagem: pacto fáustico, romance de formação e outros temas de literatura comparada. São Paulo: 34, 2010. p. 159-196.

MIGUEL-PEREIRA, Lúcia. História da literatura brasileira: prosa de ficção (de 1870 a 1920). 3 ed. Rio de Janeiro: José Olympio; Brasília: INL, 1973.

PACHECO, João. A perscrutação psicológica. In:

A literatura brasileira: 0 realismo (1870-1900). 4 ed. São Paulo: Cultrix, 1971. p. 144-151.

POMPÉIA, Raul. Obras de Raul Pompéia: O Ateneu. Rio de Janeiro: Civilização Brasileira; MEC; FENAME. 1981. v.2.

REIS, Zenir Campos. Opostos, mas justapostos. In: POMPÉIA, Raul. O Ateneu. 18 ed. São Paulo: Ática, 1998. p. 3-8.

SARAIVA, Antonio José. Introdução. In:

As crônicas de Fernão Lopes: selecionadas e transpostas em português moderno. 4 ed. Lisboa: Gradiva, 1997. p. 1732 .

SCHAPIRO, Meyer. Impressionismo: reflexões e percepções. São Paulo: Cosac \& Naify, 2002.

VALLE, Júlio. Os muitos mundos de O Ateneu. Revlet - Revista Virtual de Letras, Jataí, v. 2, n. 1, 2010. p. 95-110. Disponível em <http://www.revlet.com.br/artigos 123.pdf >. Acesso em 19 dez. 2011. 


\section{Para citar essa obra:}

SANDANELLO, F.B. Em nome do Pai: autoritarismo e discurso patriarcal n'O Ateneu, de Raul Ponpéia . In: RUA [online]. no. 22. Volume 1, p. 63-88 - ISSN 1413-2109 Novembro/2015. Consultada no Portal Labeurb - Revista do Laboratório de Estudos Urbanos do Núcleo de Desenvolvimento da Criatividade.

http://www.labeurb.unicamp.br/rua/

Capa: Disponivel em:

https://lacasadelaplayabcn.files.wordpress.com/2013/05/canetdemar.jpg

\section{Laboratório de Estudos Urbanos - LABEURB}

Núcleo de Desenvolvimento da Criatividade - NUDECRI

Universidade Estadual de Campina s - UNICAMP

http://www.labeurb.unicamp.br/

Endereço:

LABEURB - LABORATÓRIO DE ESTUDOS URBANOS

UNICAMP/COCEN / NUDECRI

CAIXA POSTAL 6166

Campinas/SP - Brasil

CEP 13083-892

Fone/ Fax: (19) 3521-7900

Contato: http://www.labeurb.unicamp.br/contato 